Published in final edited form as:

Anal Chem. 2006 November 1; 78(21): 7582-7587.

\title{
Quantitative Analysis of Trace Chromium in Blood Samples. Combination of the Advanced Oxidation Process with Catalytic Adsorptive Stripping Voltammetry
}

\author{
Li Yong, Kristie C. Armstrong, Royce N. Dansby-Sparks, Nathan A. Carrington, James Q. \\ Chambers, and Zi-Ling Xue* \\ Department of Chemistry, The University of Tennessee, Knoxville, Tennessee 37996
}

\begin{abstract}
A new method for pretreating blood samples for trace $\mathrm{Cr}$ analysis is described. The Advanced Oxidation Process (AOP with $\mathrm{H}_{2} \mathrm{O}_{2}$ and 5.5-W irradiation for $60 \mathrm{~min}$ ) is used to remove biological/ organic species for subsequent analysis. Prior to the AOP pretreatment, acid $\left(\mathrm{HNO}_{3}\right)$ is used at $\mathrm{pH}$ 3.0 to inhibit the enzyme catalase in the blood samples. Catalytic Adsorptive Stripping Voltammetry (CAdSV) at a bismuth film electrode (BiFE) gives $\mathrm{Cr}$ concentration of $6.0 \pm 0.3 \mathrm{ppb}$ in the blood samples. This concentration was confirmed by dry-ashing the blood samples and subsequent analysis by atomic absorption spectroscopy (AAS). This current method may be used to monitor chromium, a trace metal in humans, and the efficacy and safety of chromium supplements as adjuvant therapy for diabetes.
\end{abstract}

\section{Introduction}

Diabetes is a common disease that affects 16 million people in the United States, with an estimated 800,000 new cases diagnosed each year. ${ }^{1}$ Chromium is an essential trace element for mammals, ${ }^{2}$ and $\mathrm{Cr}$ complexes have been used as a dietary supplement for the treatment of diabetes and its complications. ${ }^{1}$ Chromium deficiency has also been linked to increased risk of nonfatal myocardial infarction and cardiovascular disease. ${ }^{3}$

The frequency of actual chromium deficiency in the population is unknown in part because reliable measures for assessing chromium status in humans are limited. ${ }^{4}$ Since the levels of chromium present in biological tissues and fluids are extremely low (e.g., ca. 3-10 ppb in blood of mammals ${ }^{5}$ and chromium is bound to peptides, ${ }^{2}$ many difficulties associated with finding a measure of the chromium status are analytical in nature. ${ }^{4}$ Currently there are three analytical techniques with the required sensitivity for the measurement of chromium in biological samples from humans: ${ }^{4}$ neutron activation, ${ }^{3}$ mass spectrometry (such as ICP-MS), ${ }^{4}$ and graphite furnace atomic absorption spectroscopy. ${ }^{6}$ The first two techniques require expensive instrumentation and are thus not widely available. In the chromium analysis by graphite furnace atomic absorption spectroscopy, the samples are usually heated to, e.g., $2500{ }^{\circ} \mathrm{C}$ for pretreatment and atomization. ${ }^{6}$ Heating to that high temperature is needed in part to decompose biological/organic species and to release chromium from their complexes. This technique is highly susceptible to interference from the sample matrix. ${ }^{4}$ In the ICP-MS analysis of chromium in blood and tissue samples, a pretreatment step using microwave digestion is often needed. $5 \mathrm{a}, \mathrm{e}-\mathrm{g}$ In addition, quadrupole ICP-MS is not recommended for the ppb-level chromium analysis in biological samples, as a result of interferences from residual carbon. $5 \mathrm{e}$

Supporting Information Available

Images of the photochemical reactor and effect of $\mathrm{H}_{2} \mathrm{O}_{2}$ concentration on CAdSV analysis. This material is available free of charge via the Internet at http://pubs.acs.org. 
There is an urgent need to develop improved techniques for the analysis of chromium in biological fluids to assess chromium deficiency and the effect of chromium as adjuvant therapy for Type 2 diabetes.

The Advanced Oxidation Process (AOP) is a combination of hydrogen peroxide and ultraviolet (UV) radiation (or ozone) to generate hydroxyl radicals $(\bullet \mathrm{OH}),{ }^{7 \mathrm{a}}$ and it has been used for the decomposition of organic compounds 7 and sample pretreatment. ${ }^{8,9}$ Such a process destroys organic matter in environmental or biological samples and releases metals from their complexes prior to chemical analysis. 10

There have been, to our knowledge, few studies of pretreating blood samples by AOP for

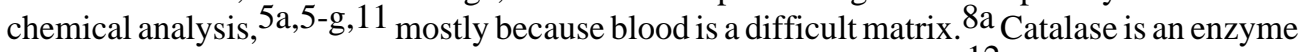
that decomposes $\mathrm{H}_{2} \mathrm{O}_{2}$ and protects the body from hydroxyl radicals. ${ }^{12}$ The enzyme is, however, detrimental to the AOP treatment of blood samples, and leads to vigorous foaming of the sample. In two papers that have reported pretreating a blood sample through oxidation processes, either a long UV irradiation ${ }^{8 \mathrm{a}}$ or a different oxidant (potassium peroxydisulfate, $\mathrm{K}_{2} \mathrm{~S}_{2} \mathrm{O}_{8}$ ) was used. ${ }^{11 \mathrm{~b}}$

We have developed a new process to pretreat blood samples. This new process combines the AOP treatment (aqueous $0.2 \% \mathrm{H}_{2} \mathrm{O}_{2}$ and a 5.5-W UV irradiation) with acid deactivation of the enzyme catalase in blood. This procedure leads to the successful decomposition of biological/organic species in blood, and the conversion of chromium in different oxidation states to chromate. Subsequent $\mathrm{Cr}$ analysis by Catalytic Adsorptive Stripping Voltammetry (CAdSV), which was recently developed by Wang and coworkers, ${ }^{13}$ yields $\mathrm{Cr}$ concentration of $6.0 \pm 0.3 \mathrm{ppb}$ in the blood samples. This Cr concentration is consistent with that $(6.19 \pm 0.03$ $\mathrm{ppb}$ for the same blood samples) determined by a combination of dry-ashing 14 and atomic absorption spectroscopy. To our knowledge, the current work is a rare, successful AOP treatment of blood samples. ${ }^{11}$ Our results are reported here.

\section{Experimental}

Pretreatment of blood samples by AOP was carried out in a 20-mL photochemical reactor shown in Figure 1. The photoreactor consisted of an outer vessel containing the sample, waterjacketed quartz immersion well, and a UV lamp. (CAUTION: UV Light can be dangerous. Wear eye protection). The reactor was designed and built in house, except for the quartz immersion well, which was purchased from Ace Glass. The UV lamp was a 5.5-W quartz lowpressure cold cathode mercury gaseous discharge lamp (Ace Glass 12132-08).

CAdSV experiments were conducted using Electrochemical Workstation $650 \mathrm{~A}(\mathrm{CH}$ Instruments, Austin, TX). The cell assembly consisted of a Bi-coated glassy carbon working electrode (3 mm diameter, Cypress Systems, 66-EE047), $\mathrm{Ag} / \mathrm{AgCl}$ reference electrode (Model CHI111, CH Instruments), and a platinum wire counter electrode. The Bi coating was prepared by a procedure similar to that developed by Wang and coworkers. ${ }^{13 \mathrm{~b}}$ A glassy carbon electrode was polished, exposed to piranha solution (CAUTION: Piranha solution reacts violently with organics and proper caution should be taken when handling), and sonicated prior to Bi coating. A $1.245 \mathrm{mg} \mathrm{L}^{-1}$ bismuth-0.1 M acetate buffer ( $\mathrm{pH} 4.5$ ) was prepared from a bismuth AA standard solution (1,000 ppm, Aldrich). The Bi coating onto the glassy carbon electrode was conducted at $-1.20 \mathrm{~V}$ for $120 \mathrm{~s}$. $\mathrm{pH}$ measurements were carried out with a pH meter (Accumet Basic, Fisher Scientific). All glassware was soaked in $1 \mathrm{M}$ nitric acid and rinsed several times with deionized water prior to use.

Potassium hydroxide (Certified ACS, Fisher), potassium nitrate (Certified ACS, Fisher), potassium oxalate (Certified ACS, Fisher), acetic acid (glacial, Fisher), nitric acid (70\%, Trace Metal Grade, Fisher), sodium acetate (anhydrous, Certified ACS, Fisher), and 
diethylenetriaminepentaacetic acid (DTPA, $\geq 99 \%$, Fluka) were used as received. $\mathrm{H}_{2} \mathrm{O}_{2}(3 \%)$ was freshly prepared from $30 \% \mathrm{H}_{2} \mathrm{O}_{2}$ (Optima Grade, Fisher) and deionized water.

(CAUTION: acetic acid and nitric acid are corrosive; hydrogen peroxide is a strong oxidizer and is corrosive). Bi and $\mathrm{Cr}(\mathrm{VI}) \mathrm{AA}$ standard solutions ( $1000 \mathrm{mg} / \mathrm{L}$, Aldrich) were diluted prior to use. The electrolyte solution contained $0.1 \mathrm{M}$ sodium acetate and $0.25 \mathrm{M} \mathrm{KNO}_{3}$, and its $\mathrm{pH}$ was adjusted to 6.0 with $\mathrm{CH}_{3} \mathrm{COOH}$. The DTPA solution $(0.1 \mathrm{M})$ was prepared by dissolving the DTPA in water while adjusting the $\mathrm{pH}$ to 6.0 with $25 \% \mathrm{NH}_{4} \mathrm{OH}$ (Fisher Scientific). $\mathrm{Cr}(\mathrm{VI})$ standards were prepared by diluting the appropriate amount of stock solution in electrolytes. Porcine blood samples were obtained from Wampler's Farm (Lenoir City, Tennessee). The blood was collected in 1-L bottles each containing $2 \mathrm{~g}$ of potassium oxalate to prevent coagulation. 16

\section{Pretreatment of blood samples by AOP}

A porcine blood sample $(0.5 \mathrm{~mL})$ was diluted with deionized $\mathrm{H}_{2} \mathrm{O}(15 \mathrm{~mL})$ in the photoreactor. Concentrated $\mathrm{HNO}_{3}$ (2 drops) was added to inhibit the enzyme catalase in blood. The color of solution changed from deep red to deep brown ( $\mathrm{pH}$ ca. 3.0). After stirring at $23^{\circ} \mathrm{C}$ for $5 \mathrm{~min}$, $\mathrm{H}_{2} \mathrm{O}_{2}(3 \%, 1.0 \mathrm{~mL})$ was added slowly to give the concentration of $\mathrm{H}_{2} \mathrm{O}_{2}$ in the mixture at ca. $2.0 \mathrm{~g} / \mathrm{L}$, and the mixture was then irradiated with the 5.5-W UV lamp for $40 \mathrm{~min}$. The photoreactor was wrapped with aluminum foil during the UV irradiation. $\mathrm{KOH}$ was then added to adjust the $\mathrm{pH}$ of the solution to 9.5. The UV irradiation was continued for an additional 20 min. The clear, faint yellow solution was analytically transferred to an electrochemical cell. $\mathrm{KNO}_{3}$ and $\mathrm{NaOAC}$ were added such that their concentrations were equal to those of the electrolyte solution. The solution volume was adjusted to $20 \mathrm{~mL}$ with deionized water, and the $\mathrm{pH}$ was then adjusted to 6.0 by concentrated acetic acid. The sample was then ready for analysis by CAdSV.

When $30 \% \mathrm{H}_{2} \mathrm{O}_{2}(1.0 \mathrm{~mL})$ was used in an otherwise identical pretreatment of the blood sample, the process gave a nearly colorless solution. However a subsequent $\mathrm{Cr}$ analysis was found to be affected by the excess $\mathrm{H}_{2} \mathrm{O}_{2}$, and the best amount of $\mathrm{H}_{2} \mathrm{O}_{2}$ for the treatment was $3 \%$ (1.0 $\mathrm{mL}) \mathrm{H}_{2} \mathrm{O}_{2}$. These findings are discussed below.

Other alternative AOP procedures were also studied. The procedure below involves a singlestep AOP treatment at $\mathrm{pH}$ ca. 3.0 for $40 \mathrm{~min}$. The error in the $\mathrm{Cr}$ analysis of samples from this shortened step is, however, ca. $10 \%$ larger than the procedure discussed above. A porcine blood sample $(0.5 \mathrm{~mL})$ was diluted with deionized $\mathrm{H}_{2} \mathrm{O}(15 \mathrm{~mL})$ in the photoreactor. Concentrated $\mathrm{HNO}_{3}$ (2 drops) was added to inhibit the enzyme catalase in blood. The color of solution changed from deep red into deep brown ( $\mathrm{pH}$ ca. 3.0). After stirring at $23{ }^{\circ} \mathrm{C}$ for $5 \mathrm{~min}, \mathrm{H}_{2} \mathrm{O}_{2}$ $(3 \%, 1.0 \mathrm{~mL})$ was added slowly, and the mixture was then UV-irradiated for $40 \mathrm{~min}$. The clear, faint yellow mixture was analytically transferred to an electrochemical cell. $\mathrm{KNO}_{3}$ and $\mathrm{NaOAC}$ were added such that their concentrations were equal to the electrolyte solution. The solution volume was adjusted to $20 \mathrm{~mL}$ by deionized water, and the $\mathrm{pH}$ was then adjusted to 6.0 by concentrated acetic acid. The sample was then ready for analysis by CAdSV.

\section{Adsorptive stripping measurements of $\mathrm{Cr}(\mathrm{VI})^{13 b}$}

After a Bi film electrode (BiFE) was prepared, standard solutions of $\mathrm{Cr}(\mathrm{VI})$ were analyzed by CAdSV. The standards ranged from 52 to $1311 \mathrm{ppt} \mathrm{Cr}(\mathrm{VI})$. The solution was first deareated with nitrogen gas for $5 \mathrm{~min}$. A DTPA solution was then added to a final concentration of 5 $\mathrm{mM}$. Adsorption was carried out by holding the voltage at $-0.8 \mathrm{~V}$ for $140 \mathrm{~s}$ while stirring. Square wave voltammetry (SWV) was performed in an unstirred solution over a potential range of -0.8 to $-1.4 \mathrm{~V}$ with a potential step of $4 \mathrm{mV}$, an amplitude of $25 \mathrm{mV}$, a frequency of $20 \mathrm{~Hz}$, and a quiet time of $8 \mathrm{~s}$. The electrode was cleaned between each measurement by applying -1.2 
$\mathrm{V}$ potential for $30 \mathrm{sec}$ in the electrolyte solution. The SWVs were baseline corrected by subtraction of the background signal.

\section{Results and Discussion Pretreatment of Blood by AOP}

Chromium is believed to be bound to a peptide whose function is part of an insulin-signaling autoamplification in mammals. ${ }^{2 \mathrm{~b}-\mathrm{c}}$ Chemical analysis of chromium in biological fluids is limited by biological/organic species and extremely low concentrations. The most common methods for the pretreatment of blood sample to release the metal ion include dry-ashing or wet-ashing. ${ }^{14}$ Dry-ashing involves high temperatures in an oxygen-rich environment, and wetashing uses strong acids. Both pretreatment procedures are time consuming and prone to contaminations.

In recent years, the Advanced Oxidation Process has emerged as a powerful method to release metal ions from biological/organic species. The Advanced Oxidation Process combines $\mathrm{H}_{2} \mathrm{O}_{2}$ and $\mathrm{O}_{3}$ or ultra-violet radiation to yield hydroxyl radicals $(\bullet \mathrm{OH})$, a very potent oxidant. $7 \mathrm{a}$ The standard reduction potential of $\bullet \mathrm{OH}$ is $2.8 \mathrm{~V}$. In comparison, the standard reduction potentials of $\mathrm{O}_{3}, \mathrm{H}_{2} \mathrm{O}_{2}$ and $\mathrm{Cl}_{2}$, three other strong oxidants, are $2.07,1.78$ and $1.35 \mathrm{~V}$, respectively. The products of AOP are water, $\mathrm{CO}_{2}$, and free metal ions. Intrigued by the potential use of AOP in blood treatment, we have previously examined and proven the feasibility of releasing of $\mathrm{Cr}$ (III) from the biomimetic chromium species chromium(III) propionate. 17

When $\mathrm{H}_{2} \mathrm{O}_{2}$ was added to a diluted blood sample, vigorous foaming due to the decomposition of $\mathrm{H}_{2} \mathrm{O}_{2}$ by the enzyme catalase was observed. Although this enzyme protects the body from hydroxyl radicals, ${ }^{12}$ the process to decompose $\mathrm{H}_{2} \mathrm{O}_{2}$ is detrimental to the AOP treatment of blood samples. The effect and the optimal amount of $\mathrm{H}_{2} \mathrm{O}_{2}$ for AOP treatment are discussed below.

To inhibit catalase activity, several reagents such as copper(II) sulfate, sodium cyanide, sodium azide, nitric acid, sodium- $n$-dodecyl sulphate (SDS), and 3-aminotriazole (ATA) have been used in the literature. ${ }^{18}$ In choosing an optimal inhibitor for the deactivation of blood samples in the current work, we considered the following factors: (1) toxicity of the reagents - both $\mathrm{NaCN}$ and $\mathrm{NaN}_{3}$ are extremely toxic; (2) the use of organic inhibitors such as SDS and 3aminotriazole (ATA) requires their subsequent decomposition in the AOP step; (3) introduction of metal ions (in the use of $\mathrm{CuSO}_{4}$ ) to the blood samples that may potentially contaminate the samples; (4) the use of $\mathrm{KNO}_{3}$ in subsequent electrochemical detection of $\mathrm{Cr}(\mathrm{VI})$ by CAdSV. $13 \mathrm{~b}$ We thus chose $\mathrm{HNO}_{3}$ as the catalase inhibitor in the current work. Our tests revealed that the optimal $\mathrm{pH}$ for catalase inhibition was 3.0. To decompose the catalase and prevent the foaming, a $40 \mathrm{~min}$ irradiation of the sample under this acidic condition was essential.

Our earlier work on the AOP pretreatment of chromium(III) propionate, a biomimetic chromium species, revealed that the optimal $\mathrm{pH}$ for $100 \%$ conversion of $\mathrm{Cr}$ (III) to $\mathrm{Cr}$ (VI) by AOP was 9.5. ${ }^{17}$ Therefore, after the initial 40 min irradiation under acidic condition, a second AOP treatment of the blood sample at $\mathrm{pH} 9.5$ for 20 min was used. Direct AOP treatment of blood sample under basic condition, or elimination of the first $40 \mathrm{~min}$ irradiation under acidic condition, was found to lead to vigorous foaming. Thus, AOP treatment at low $\mathrm{pH}$ followed by subsequent treatment at high $\mathrm{pH}$ was found necessary for complete and reproducible $\mathrm{Cr}$ (III) to $\mathrm{Cr}(\mathrm{VI})$ conversion.

The effect of AOP on the blood sample was visibly evident. When the blood sample was treated with $1.0 \mathrm{~mL}$ of $3 \% \mathrm{H}_{2} \mathrm{O}_{2}$, the bright red mixture turned to a clear, faint yellow solution. The 
pretreatment method using $1.0 \mathrm{~mL}$ of $30 \% \mathrm{H}_{2} \mathrm{O}_{2}$ in an otherwise identical process turned the blood sample from a bright red mixture to a clear, nearly colorless solution with no observable precipitation (Figure 2). As discussed below, using $1.0 \mathrm{~mL}$ of $3 \% \mathrm{H}_{2} \mathrm{O}_{2}$ in the AOP treatment leads to more accurate $\mathrm{Cr}$ analyses by the CAdSV process. The procedure with $1.0 \mathrm{~mL}$ of $30 \%$ $\mathrm{H}_{2} \mathrm{O}_{2}$ is thus presented as an option.

\section{Measurement of the pretreated blood samples by CAdSV}

CAdSV has shown very good sensitivity and low detection limits in the determination of ultratrace concentration of metals. ${ }^{20}$ The Adsorptive Stripping Voltammetry (AdSV) technique is based on the accumulation of the analyte metal on a suitable working electrode by potential-controlled adsorption and subsequent electrochemical oxidation or reduction of the preconcentrated species. Coupling the adsorptive accumulation with a catalytic action leads to a significant increase of the analytical signal and the sensitivity of detection. Wang and coworkers recently developed the detection of $\mathrm{Cr}(\mathrm{VI})$ using Bi film electrode $(\mathrm{BiFE})$ and CAdSV with a detection limit of $15.6 \mathrm{ppt} \mathrm{Cr}(\mathrm{VI}) .{ }^{13 \mathrm{~b}}$ In this procedure, $\mathrm{Cr}(\mathrm{VI})$ is reduced to $\mathrm{Cr}$ (III) electrochemically on the BiFE, and $\mathrm{Cr}$ (III) then binds to DTPA to yield an electroactive species $\left[\mathrm{Cr}^{\mathrm{III}}\left(\mathrm{H}_{2} \mathrm{O}\right) \mathrm{HY}\right]^{-} 20 \mathrm{~d}-\mathrm{e}$ which is adsorbed onto the BiFE surface. $\left[\mathrm{Cr}^{\mathrm{III}}\left(\mathrm{H}_{2} \mathrm{O}\right) \mathrm{HY}\right]^{-}$is further reduced to $\left[\mathrm{Cr}^{\mathrm{II}} \mathrm{H}_{2} \mathrm{Y}\right]^{-}$electrochemically at $-1.1 \mathrm{~V}$. Nitrate in the electrolyte solution oxidizes the $\mathrm{Cr}(\mathrm{II})$ species back to $\mathrm{Cr}(\mathrm{III})\left[\mathrm{Cr}^{\mathrm{III}}\left(\mathrm{H}_{2} \mathrm{O}\right) \mathrm{HY}\right]^{-}$in a catalytic cycle, which significantly increases the SWV signal. Scheme 1 outlines this cycle. ${ }^{20 \mathrm{~d}-\mathrm{e}}$

With the mechanism of the CAdSV(?) technique in mind, it is not difficult to understand the important role of electrolytes in precise CAdSV analyses. As shown in Figure 3, the effect of electrolytes in the CAdSV measurement of the AOP pretreated blood samples was quite clear. CAdSV was directly performed on an AOP pretreated blood sample (Sample 1) and a sample after the addition of electrolytes $\left(\mathrm{KNO}_{3}\right.$ and $\mathrm{NaOAC}$ to concentrations of $0.25 \mathrm{M}$ and $0.1 \mathrm{M}$, respectively) and adjusting the $\mathrm{pH}$ to 6.0 (Sample 2). Without the electrolytes, the current peak for Sample 1 is suppressed.

\section{Effects of $\mathrm{H}_{2} \mathrm{O}_{2}$ on both blood pretreatment by AOP and measurement by CAdSV}

One critical factor in $\mathrm{AOP}$ is the concentration of $\mathrm{H}_{2} \mathrm{O}_{2}$ during the $\mathrm{UV}$ irradiation. The role of $\mathrm{H}_{2} \mathrm{O}_{2}$ in AOP includes: (1) decomposition of organic ligands in blood samples, and (2) conversion of $\mathrm{Cr}$ at low oxidation states to $\mathrm{Cr}(\mathrm{VI})$ species. However, a high concentration of $\mathrm{H}_{2} \mathrm{O}_{2}$ is not desirable due to its negative influence in blood treatment and measurement. For blood pretreatment using AOP, a large concentration of hydroxyl radicals $(\bullet \mathrm{OH})$ increases the rate of their recombination, thus decreasing the AOP rate. ${ }^{7 \mathrm{a}}$ Also, for measurements using CAdSV, a large excess of $\mathrm{H}_{2} \mathrm{O}_{2}$ in solution likely affects the catalytic cycle, as the mechanism in Scheme 1 suggests. The excessive $\mathrm{H}_{2} \mathrm{O}_{2}$ probably oxidizes the $\mathrm{Cr}$ (II) species back to $\mathrm{Cr}$ (III) $\left[\mathrm{Cr}^{\mathrm{III}}\left(\mathrm{H}_{2} \mathrm{O}\right) \mathrm{HY}\right]^{-}$and may affect the accuracy of measurement. Thus, several experiments have been conducted to find the appropriate concentration of $\mathrm{H}_{2} \mathrm{O}_{2}$ which is both sufficient for AOP reaction and acceptable for measurement. ${ }^{15} \mathrm{Cr}(\mathrm{VI})$ standard solutions (2.6 ppb) containing $0.0 \mathrm{~g} / \mathrm{L}, 1.5 \mathrm{~g} / \mathrm{L}, 3.0 \mathrm{~g} / \mathrm{L}$ and $8.3 \mathrm{~g} / \mathrm{L}$ of $\mathrm{H}_{2} \mathrm{O}_{2}$ were analyzed by CAdSV. The influence of $\mathrm{H}_{2} \mathrm{O}_{2}$ at $1.5 \mathrm{~g} / \mathrm{L}$ concentration level was found negligible (Table 1). In separate studies, AOP treatments of blood samples $(0.5 \mathrm{~mL}$ diluted to $15 \mathrm{~mL})$ were conducted with the $\mathrm{H}_{2} \mathrm{O}_{2}$ concentrations ranging from $0.75 \mathrm{~g} / \mathrm{L}$ to $16.65 \mathrm{~g} / \mathrm{L}$. Each sample was $\mathrm{UV}$-irradiated in the 20$\mathrm{mL}$ photoreactor for $40 \mathrm{~min}$. After careful screening, $2.0 \mathrm{~g} / \mathrm{L} \mathrm{of} \mathrm{H}_{2} \mathrm{O}_{2}$ was found to be sufficient for the AOP treatment of the blood samples, and the concentration of $\mathrm{H}_{2} \mathrm{O}_{2}$ at up to $2.0 \mathrm{~g} / \mathrm{L}$ does not interfere with the $\mathrm{Cr}(\mathrm{VI})$ measurement by CAdSV.

\section{Calibration plot and measurement of blood samples}

The SWVs and corresponding calibration plot for Cr(VI) standards measured by CAdSV at a BiFE in the current work are shown in Figure 4. The non-zero intercept on the calibration plot 
in Figure $4 \mathrm{~b}$ is believed to be due to a Faradaic background current as a result of uncatalyzed reduction of nitrate in the absence of the $\mathrm{Cr}$ catalyst. With the standard calibration plot in hand, blood samples pretreated using AOP for $60 \mathrm{~min}$ (two UV irradiations) and a shorter $40 \mathrm{~min}$ (one UV irradiation) were analyzed by CAdSV. The blood samples treated by AOP for $60 \mathrm{~min}$ gave $\mathrm{Cr}$ concentrations of $6.0 \pm 0.3 \mathrm{ppb}$. The $\mathrm{Cr}$ analysis of the sample after the shorter $(40$ min) AOP pretreatment yielded $5.4 \pm 0.3 \mathrm{ppb}$. As discussed below, dry-ashing followed by AA analysis as well as $\mathrm{Cr}$ spiking tests of the same blood sample gave Cr concentration of 6.19 \pm 0.03 and $6.1 \pm 0.2 \mathrm{ppb}$, respectively. In other words, the pretreatment using two UV irradiations, first at $\mathrm{pH}$ ca. 3.0 for $40 \mathrm{~min}$ and then at $\mathrm{pH} 9.5$ for $20 \mathrm{~min}$, gives more accurate $\mathrm{Cr}(\mathrm{VI})$ concentration of the blood sample. This finding is in accord with our previous study on the AOP pretreatment of biomimetic chromium(III) propionate. ${ }^{17}$

Standard spiking is commonly used in analytical chemistry as a means of method validation. To test the accuracy and sensitivity of our technique, we spiked two blood samples with known amounts of $\mathrm{Cr}(\mathrm{VI})$ : $260 \mathrm{ppt} \mathrm{Cr}(\mathrm{VI})$ and $780 \mathrm{ppt} \mathrm{Cr}(\mathrm{VI})$ in separate tests. ${ }^{15} \mathrm{CAdSV}$ analysis of these two blood samples gave $\mathrm{Cr}(\mathrm{VI})$ concentrations of 414 ppt and 927 ppt, respectively (Figure 5). This gives $\mathrm{Cr}(\mathrm{VI})$ concentrations in the blood of $6.2 \mathrm{ppb}$ and $5.9 \mathrm{ppb}$ after the subtraction of the spiked standard. These concentrations correspond to the data obtained by direct analysis of the blood, and their average is $97 \%$ of the value from dry-ashing and AAS, which is discussed below.

\section{Determination of the chromium concentration in the blood samples by dry-ashing}

Dry-ashing and subsequent $\mathrm{Cr}$ analysis by AAS of the blood samples was conducted to assess the accuracy of the $\mathrm{Cr}$ analysis by combination of AOP with CAdSV developed in the current work.

In the current studies using dry-ashing and AAS, a sample from the blood batch used in AOP (and subsequent analysis by CAdSV) was dry-ashed by heating a 100-mL (100.0303 g) sample slowly and gently on a flame in a large evaporating dish to remove water. After the volume of the sample was decreased by $50 \%$, the temperature of the flame was increased and the sample was heated for $3 \mathrm{~h}$. The sample was then carefully transferred to a quartz crucible and heated for another $2 \mathrm{~h}$ until only a small amount of inorganic residue remained. The weight of the final residue with a brick-red color was $0.9386 \mathrm{~g}$. This residue was then dissolved in $10 \mathrm{~mL}$ of concentrated $\mathrm{HNO}_{3}$. The solution was heated at $70^{\circ} \mathrm{C}$ until all solid was dissolved. The solution was heated to concentrate the volume to $1 \mathrm{~mL}$. Atomic absorption spectroscopy was then used for the measurement of the $\mathrm{Cr}$ concentration of the solution. The $\mathrm{Cr}$ concentration in the blood was found to be $6.19 \pm 0.03 \mathrm{ppb}$.

\section{Conclusion}

The current work shows chromium content at the ppb level in blood samples is easily analyzed through the use of the Advanced Oxidation Process $\left(\mathrm{H}_{2} \mathrm{O}_{2}\right.$ and 5.5-W UV irradiation), followed by CAdSV using a BiFE. The concentration of $6.0 \pm 0.3 \mathrm{ppb}$ chromium in the AOP-treated sample is consistent with that determined by a combination of dry-ashing and AAS. AOP, after the chemical deactivation of the enzyme catalase, offers a fast, clean and inexpensive method for removing organic biological/organic species in blood.

\section{Supplementary Material}

Refer to Web version on PubMed Central for supplementary material. 


\section{Acknowledgements}

Acknowledgement is made to the National Institutes of Health (5R21DK068107-02) for financial support, Wampler's Farm for supplying the porcine blood samples, D. Lynn Rodman for help, and Prof. Joseph Wang and Dr. S. Thongngamdee for advice.

\section{References}

1. Anderson RA. J Am Coll Nutr 1998;17:548. [PubMed: 9853533]Anderson RA. Nutr Res Rev 2003;16:267.Ryan GJ, Wanko NS, Redman AR, Cook CB. Ann Pharmacotherapy 2003;37:876.Katz, SA.; Salem, H. The Biological and Environmental Chemistry of Chromium. VCH; Weinheim: 1994.

2. Schwarz K, Mertz W. Arch Biochem Biophys 1959;85:292. [PubMed: 14444068]Vincent JB. Acc Chem Res 2000;33:503. [PubMed: 10913239]Jacquamet L, Sun Y, Hatfield J, Gu W, Cramer SP, Crowder MW, Lorigan GA, Vincent JB, Latour J-M. J Am Chem Soc 2003;125:774. [PubMed: 12526678]Dinakarpandian, D.; Morrissette, V.; Chaudhary, S.; Amini, K.; Bennett, B.; Van Horn, JD. BMC Chem Biol. http://www.biomedcentral.com/1472-6769/4/2

3. Guallar E, Jiménez FJ, van 't Veer P, Bode P, Riemersma RA, Gómez-Aracena J, Kark JD, Arab L, Kok FJ, Martín-Moreno JM. Am J Epidemiol 2005;162:157. [PubMed: 15972934]Rajpathak S, Rimm EB, Li T, Morris JS, Stampfer MJ, Willett WC, Hu FB. Diabetes Care 2004;27:2211. [PubMed: 15333486]Juturu, V.; Komorowski, JR. Advances in Heart Failure; Proceedings of the World Congress on Heart Failure: Mechanisms and Management, 8th; Washington, DC. Bologna, Italy: Medimond; 2002. p. 279-282.

4. Veillon C, Patterson KY. J Trace Elem Exp Med 1999;12:99.

5. Granadillo VA, Parra de Machado L, Romero RA. Anal Chem 1994;66:3624. [PubMed: 7802253] Veillon C, Lewis SA, Patterson KY, Wolf WR, James M, Versieck J, Vanballenberge L, Cornelis R, O'Haver TC. Anal Chem 1985;57:2106. [PubMed: 4051188]Veillon C, Patterson KY, Bryden NA. Clin Chem 1982;28:2309. [PubMed: 7127780]Morris BW, MacNeil S, Stanley K, Gray TA, Fraser R. J Endocrinol 1993;139:339. [PubMed: 8308470]Kunze J, Wimmer MA, Reich M, Koelling S, Jacobs JJ. At Spectros 2005;26:8. Bocca B, Alimonti A, Forte G, Petrucci F, Pirola C, Senofonte O, Violante N. Anal Bioanal Chem 2003;377:65. [PubMed: 12827338]Rodushkin I, Odman F, Olofsson R, Axelsson MD. J Anal At Spectrom 2000;15:937.

6. See, e.g., Rükgauer M, Zeyfang A. Biol Trace Elem Res 2002;86:193. [PubMed: 12019517]Morris BW, MacNeil S, Stanley K, Gray TA, Fraser R. J Endocrinol 1993;139:339. [PubMed: 8308470] Kortenkamp A. Cytotoxic, Mutagenic and Carcinogenic Potential of Heavy Metals Related to Human Environment. NATO ASI Series, Series 2: Environment 1997;26:35.Granadillo VA, de Machado LP, Romero RA. Anal Chem 1994;66:3624. [PubMed: 7802253]

7. Schulte P, Bayer A, Kuhn F, Luy Th, Volkmer M. Ozone-Sci Eng 1995;17:119.Safarzadeh-Amiri A. Water Res 2001;35:3706. [PubMed: 11561633]Beltran FJ, Gonzalez M, Rivas J, Marin M. Ind Eng Chem Res 1994;33:125.Sigman ME, Buchanan AC III, Smith SM. J Adv Oxidation Technol 1997;2:415.Castaldi FJ, Richardson CF, Payne B. Proceedings - WEFTEC '96 1996;3:275.

8. For recent reviews, see Golimowski J, Golimowska K. Anal Chim Acta 1996;325:111.Capelo-Martínez JL, Ximénez-Embún P, Madrid Y, Cámara C. Trends Anal Chem 2004;23:331.Apostoli P. J Chromat B 2002;778:63.

9. Direct UV irradiation without $\mathrm{H}_{2} \mathrm{O}_{2}$, ozonation, and ultrasonic irradiation (through extreme temperatures and pressures) have also been used as extraction and decomposition methods. See, e.g., Ref. 8b and Capelo JL, Lavilla I, Bendicho C. Anal Chem 2000;72:4979. [PubMed: 11055718]

10. Ping L, Dasgupta PK. Anal Chem 1989;61:1230. [PubMed: 2757207]Ritsema R, van Heerde E. Fresenius J Anal Chem 1997;358:838.Atallah RH, Kalman DA. Talanta 1991;38:167.Guéguen C, Belin C, Thomas BA, Monna F, Favarger P-Y, Dominik J. Analy Chim Acta 1999;386:155.Begerow J, Turfeld M, Dunemann L. Fresenius' J Anal Chem 1997;359:427.Krachler M, Alimonti A, Petrucci F, Irgolic KJ, Forastiere F, Caroli S. Anal Chim Acta 1998;363:1.

11. Pisch J, Schaefer J, Frahne D. GIT Fachz Lab 1993;37:500.He B, Jiang G-B, Xu XB. Fresen J Anal Chem 2000;368:803.

12. Berg, JM.; Tymoczko, JL.; Stryer, L. Biochemistry. 5. Freeman; New York: 2002. p. 506

13. Wang J, Lu J, Hocevar SB, Farias PA, Ogorevc B. Anal Chem 2000;72:3218. [PubMed: 10939390] Lin L, Lawrence NS, Thongngamdee S, Wang J, Lin Y. Talanta 2005;65:144.For other methods that 
give CrVI concentrations at ppt to low ppb range, see, e.g., Turyan I, Mandler. Anal Chem 1997;69:894.Ge H, Zhang J, Wallace GG. Analy Lett 1992;25:429. Yang Y-J, Huang H-J. Anal Chem 2001;73:1377.Zevin M, Reisfeld R, Oehme I, Wolfbeis OS. Sens Actuators 1997;B38-39:235.Carrington NA, Yong L, Xue Z-L. Anal Chim Acta. 2006in press

14. Bock, RA. Handbook of Decomposition Methods in Analytical Chemistry. Ch. 5. Wiley; New York: 1979.

15. See Supporting Information for details and a separate calibration plot for the spiking tests

16. Standard blood collection tubes, such as Vacutainer ${ }^{\circledR}$ from Beckton, Dickinson, and Company (www.BD.com), contain $2 \mathrm{mg} / \mathrm{mL}$ of potassium oxalate (an anticoagulant) and $2.5 \mathrm{mg} / \mathrm{mL}$ of sodium fluoride (a preservative). We modified this standard procedure to contain just the anticoagulant.

17. Rodman DL, Carrington NA, Xue Z-L. Talanta. 2006in pressRodman, DL. Ph.D. Thesis. The University of Tennessee; Knoxville: 2005. p. 69

18. Ito O. Nippon Jui Chikusan Daigaku Kiyo (Bull Nippon Vet Zootech Coll) 1974;23:45.Ghadermarzi M, Moosavi-Movahedi AA, Ghadermarzi M. Biochim Biophys Acta 1999;1431:30. [PubMed: 10209276]

19. Ferric ions $\mathrm{Fe}\left(\mathrm{H}_{2} \mathrm{O}\right)_{6}{ }^{3+}$ in the solution after the AOP treatment may account for the faint color in Figure 2 (right). See the Experimental section for details of this procedure using $30 \% \mathrm{H}_{2} \mathrm{O}_{2}$

20. Wang J. Electroanalysis 2005;17:1341.Wang J, Thongngamdee S, Lu D. Electroanalysis 2006;18:59.Kefala G, Economou A, Sofoniou M. Talanta 2006;68:1013.Li Y, Xue H. Anal Chim Acta 2001;448:121.Sander S, Navratil T, Novotny L. Electroanalysis 2003;15:1513. 


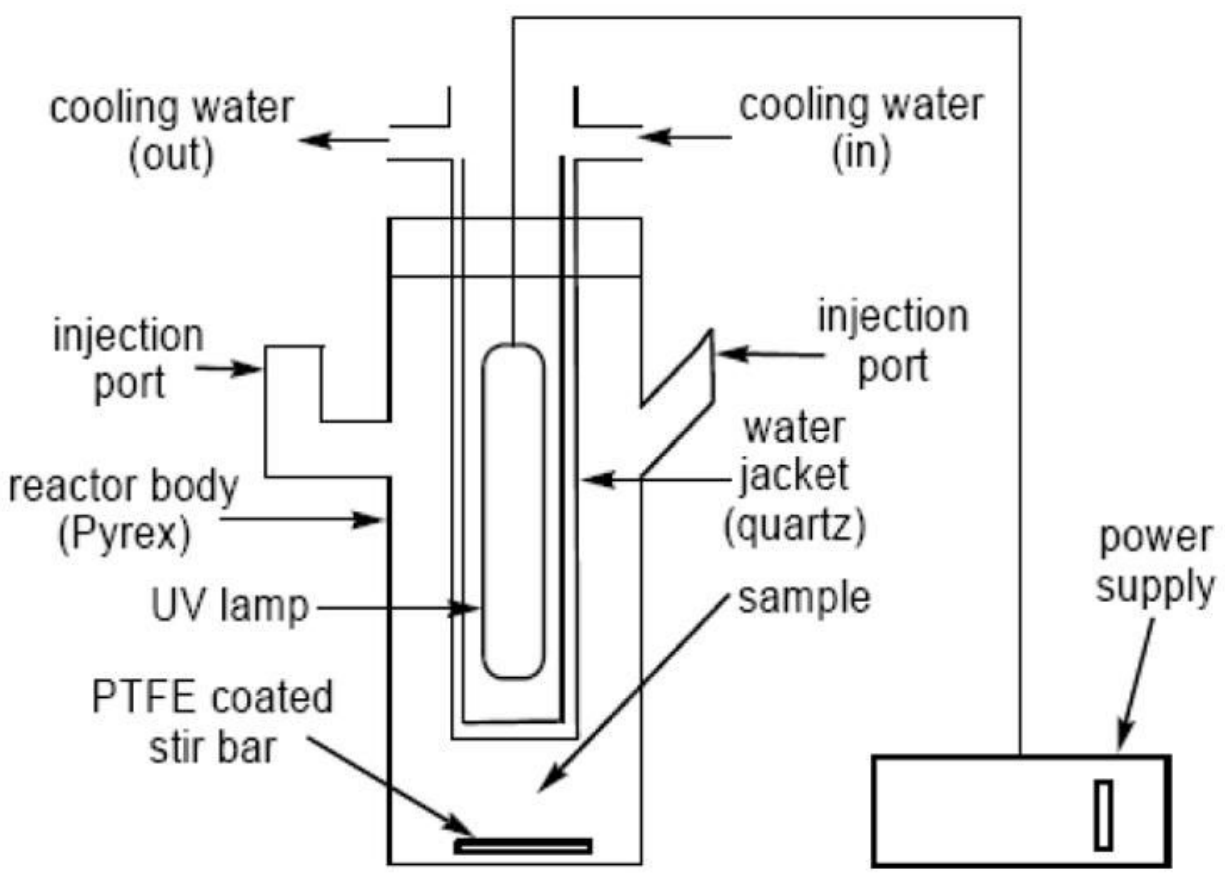

Figure 1.

Schematic of photochemical reactor used in AOP experiments. 15 


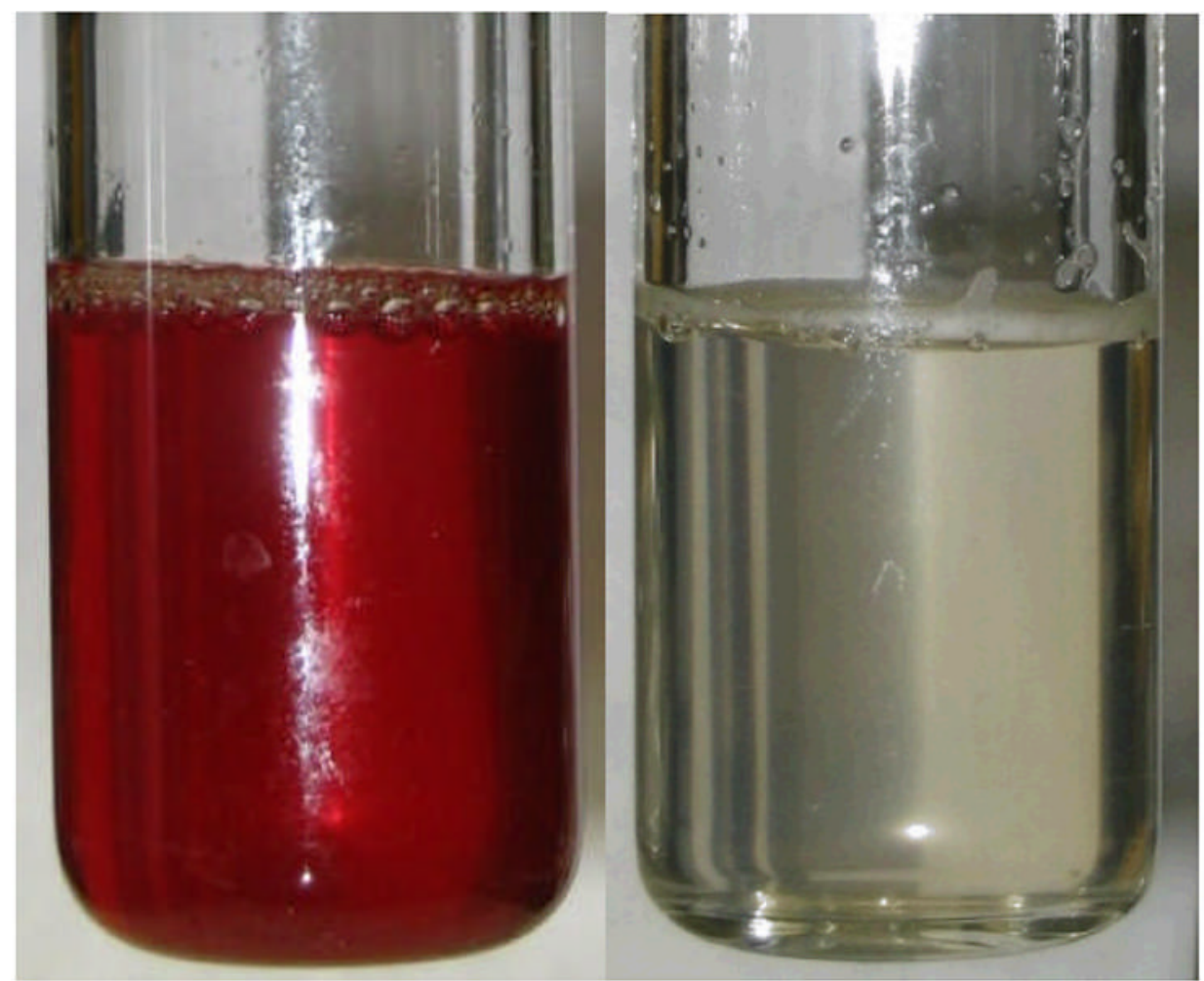

Figure 2.

Blood samples before (left) and after (right) AOP with $\mathrm{H}_{2} \mathrm{O}_{2} .{ }^{19}$ 


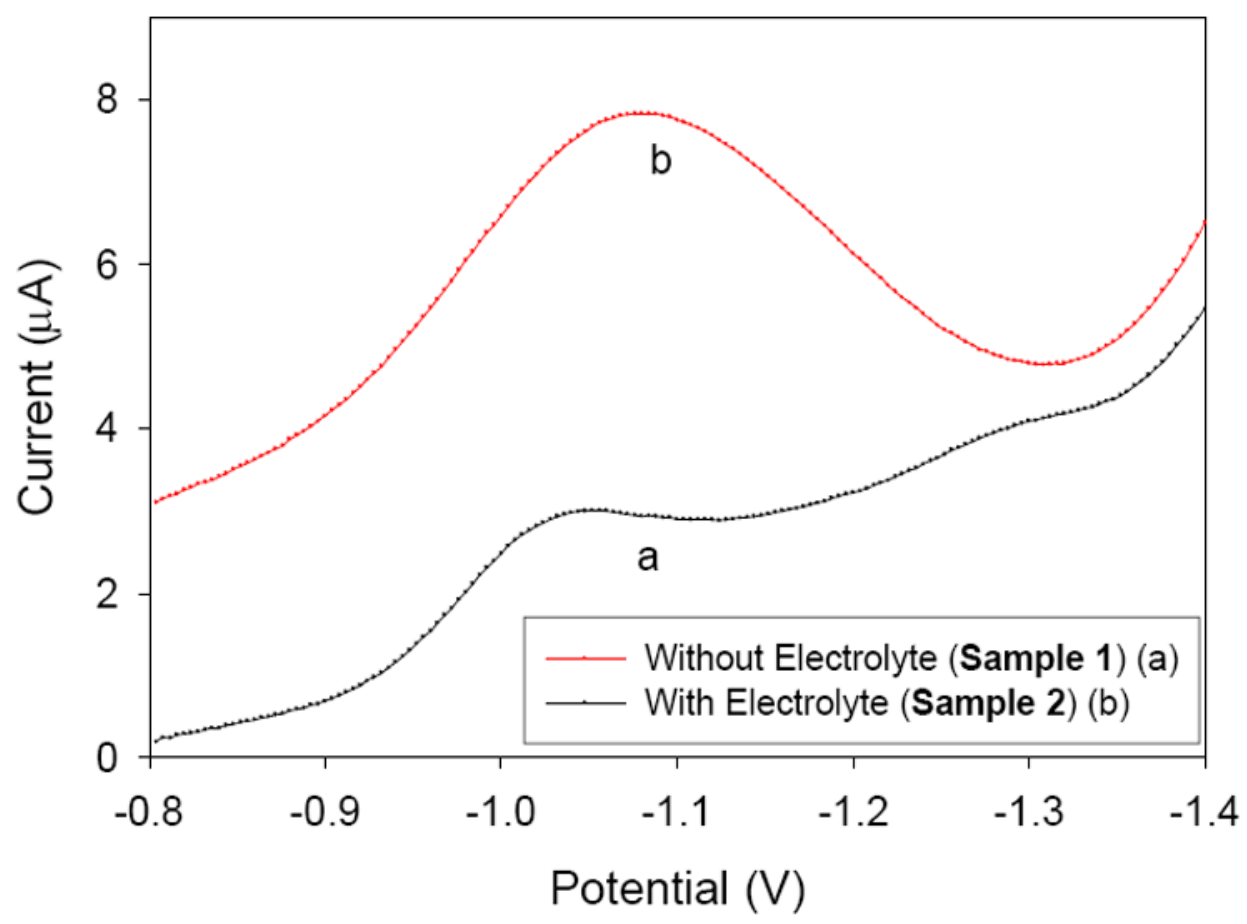

Figure 3.

Square-wave voltammagrams of AOP-treated blood samples with and without electrolytes. 

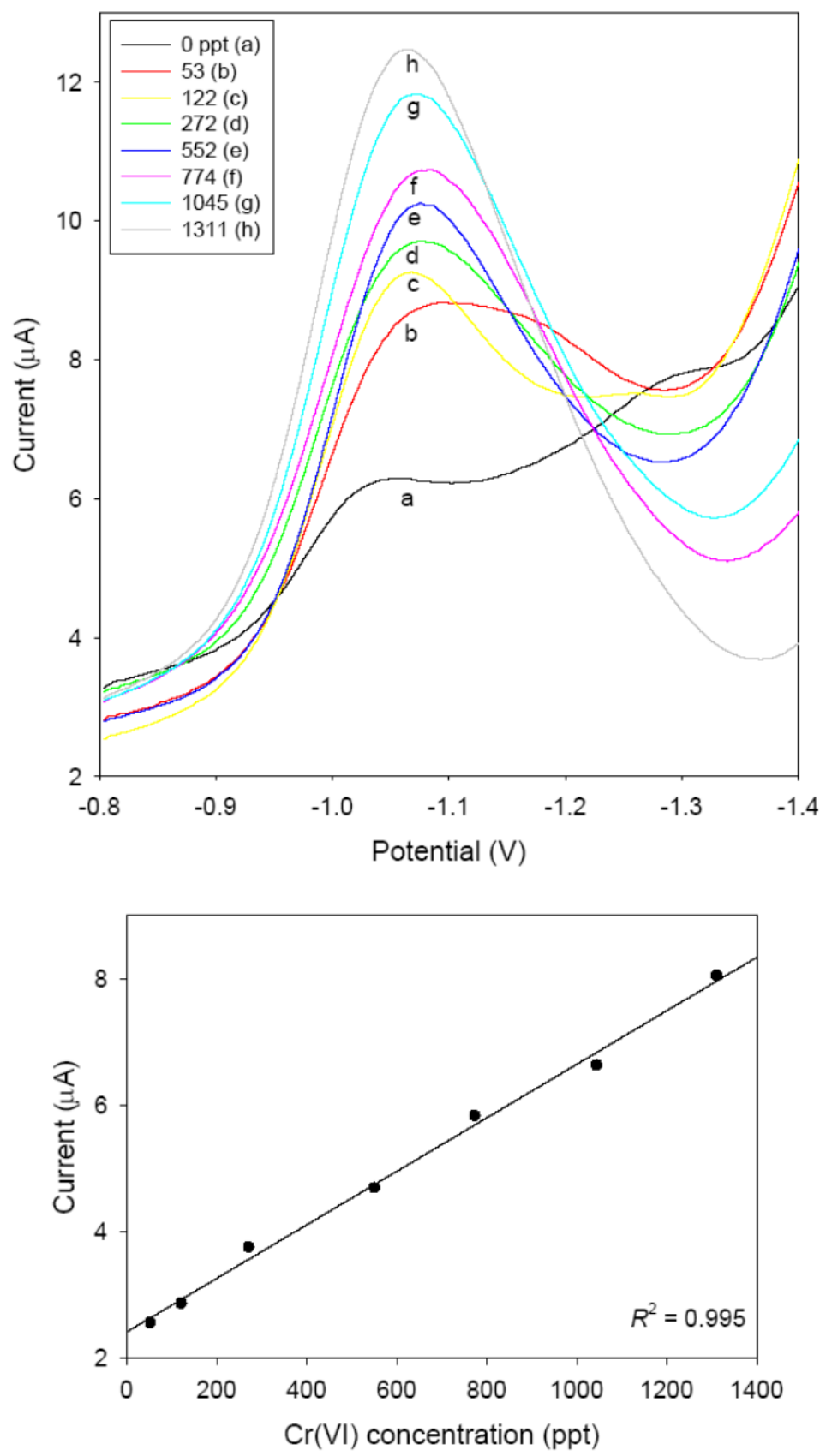

Figure 4.

Square wave voltammagrams (top) and corresponding calibration plot (bottom) of $\mathrm{Cr}(\mathrm{VI})$ standard solutions measured by CAdSV at a BiFE. The current of the blank was subtracted from those of samples in the calibration plot. 


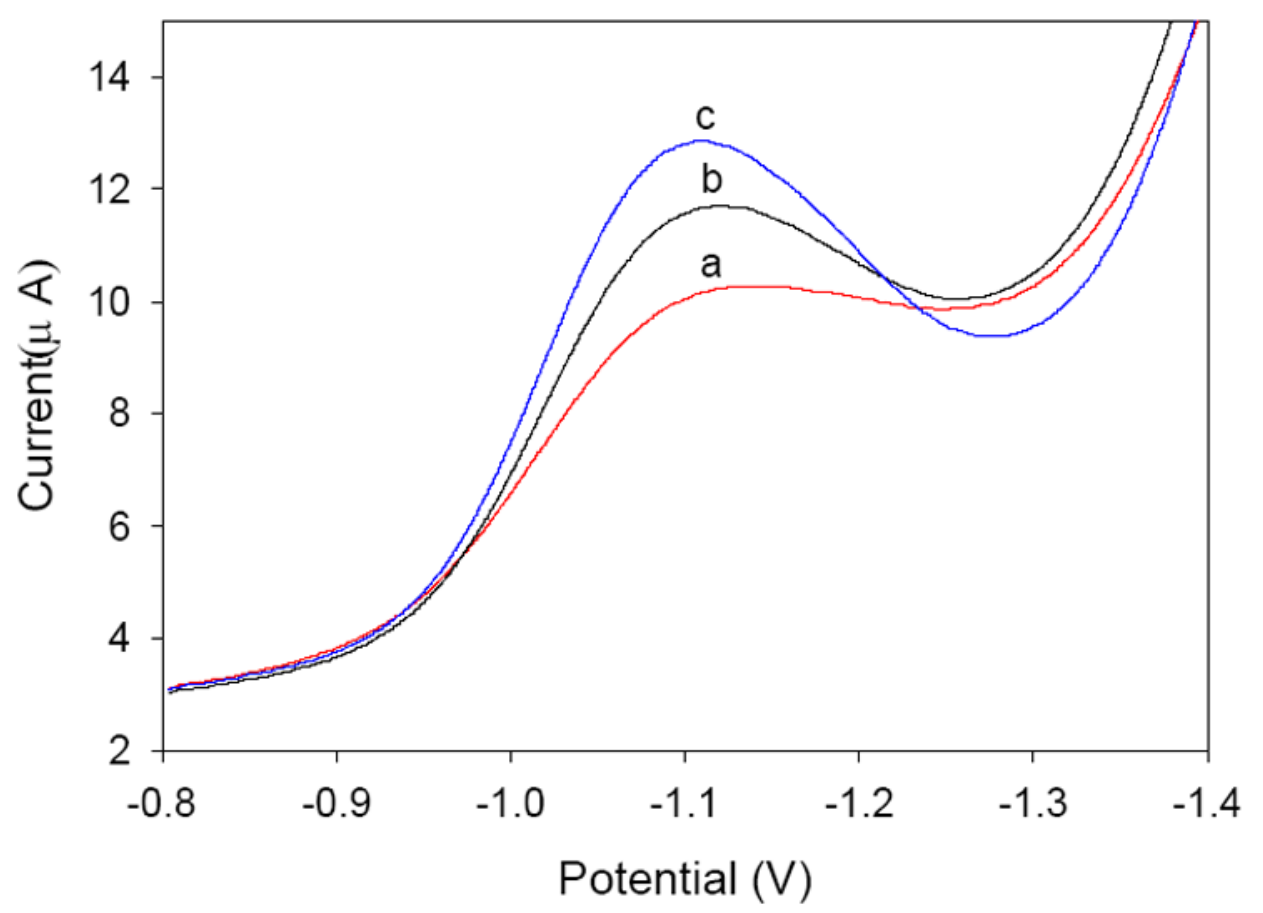

Figure 5.

SWVs of AOP pretreated blood samples spiked with $0 \mathrm{ppt}$ (red), $260 \mathrm{ppt}$ (black), and $780 \mathrm{ppt}$ (blue) $\mathrm{Cr}(\mathrm{VI}){ }^{15}$ 

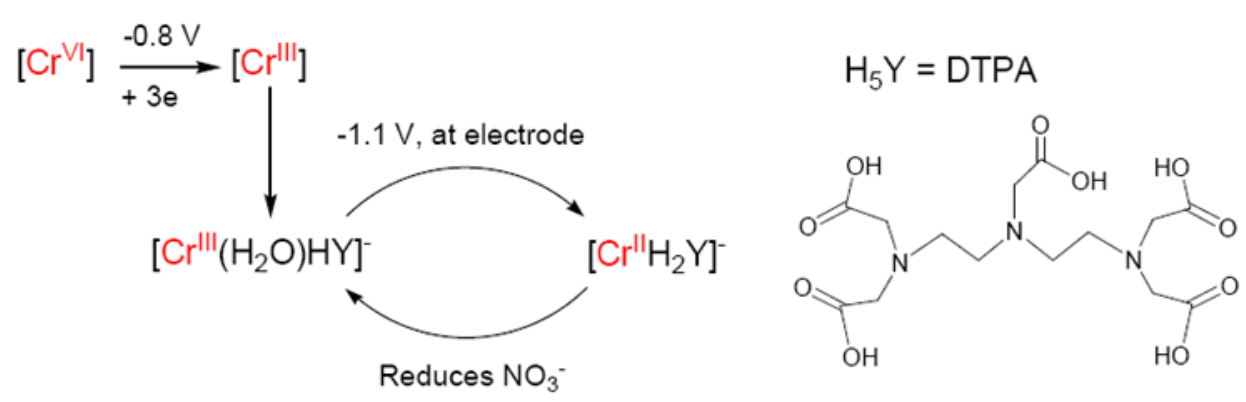

Scheme 1.

Mechanistic pathway in the detection of $\mathrm{Cr}(\mathrm{VI})$ species. ${ }^{20 \mathrm{~d}-\mathrm{e}}$ 
Table 1

The effect of $\mathrm{H}_{2} \mathrm{O}_{2}$ concentration on CAdSV analysis of standard $2.6 \mathrm{ppb} \mathrm{Cr}(\mathrm{VI})$ solutions (total volume: 20 $\mathrm{mL})$ Solutions

Blank (buffer) SWV current $(\boldsymbol{\mu A})$

$2.6 \mathrm{ppb} \mathrm{Cr}(\mathrm{VI})$

12.75

\begin{tabular}{ll}
$2.6 \mathrm{ppb} \mathrm{Cr}(\mathrm{VI})+1.5 \mathrm{~g} / \mathrm{L}$ of $\mathrm{H}_{2} \mathrm{O}$ & 20.38 \\
\hline
\end{tabular}

$2.6 \mathrm{ppb} \mathrm{Cr}(\mathrm{VI})+3.0 \mathrm{~g} / \mathrm{L}$ of $\mathrm{H}_{2} \mathrm{O}_{2}$

20.54

$2.6 \mathrm{ppb} \mathrm{Cr}(\mathrm{VI})+$ 